\title{
Duodeno-duodenal intussusception secondary to a Brunner's gland adenoma
}

\author{
S Mewa Kinoo, ${ }^{1}$ R Naidoo, ${ }^{1}$ B Singh ${ }^{2}$ \\ ${ }^{1}$ Specialist Surgeons, King Edward VIII Hospital. Honorary Lecturers, Department of General Surgery, University of KwaZulu \\ Natal, Nelson R Mandela School of Medicine \\ ${ }^{2}$ Chief Specialist Surgeon, King Edward VIII Hospital. Professor, Department of General Surgery, University of KwaZulu \\ Natal, Nelson R Mandela School of Medicine
}

Corresponding author: Suman Mewa Kinoo (smewakinoo@gmail.com)

\begin{abstract}
Summary: Duodenal intussusception is a rare complication of a Brunner's gland adenoma with only 12 cases, including this report, reported to date. Symptoms are usually vague, diagnosis is often difficult and intussusception, due to its rarity, may mimic sinister tumours. Management usually involves a duodenotomy and excision of the adenoma. We present a 46-yearold female who presented with features of intermittent gastric outlet obstruction with associated anaemia. A combination of fluoroscopy, endoscopy and computed tomography revealed a duodenal intussusception with a lead point from the $1^{\text {st }}$ part of the duodenum intussuscepting into the $4^{\text {th }}$ part of the duodenum. At laparotomy the Brunner's adenoma was removed via an antrotomy. A Brunner's gland adenoma must be suspected for tumours arising in the $1^{\text {st }}$ part of the duodenum. Though rare, intussusception may mimic more sinister tumours and must be considered as an alternate diagnosis to prevent unnecessary major resections. Excision via an antrotomy rather than a duodenotomy should be considered.

Key Words: Brunner's gland, Brunner's gland adenoma, duodenal intussusception, duodeno-jejunal intussusception
\end{abstract}

S Afr J Surg 2018;56(1)

http://dx.doi.org/10.17159/2078-5151/2018/v56n1a2292

\section{Introduction}

Brunner's gland adenomas are largely benign tumours located predominately in the first part of the duodenum. They rarely become symptomatic, and if they do, often present with upper gastrointestinal bleeds. Obstruction and intussusception rarely occur due to tumours seldom growing greater than $2 \mathrm{~cm}$ in size. Despite the rarity of intussusception, our review of all documented cases demonstrates that this is a difficult diagnosis due to the vague symptomatology. On several occasions extended resections have been performed due to a preoperative misdiagnosis. In this case report we bring to attention the various presentations that may raise suspicion of this condition and the diagnostic modalities that may be helpful in a making a preoperative diagnosis, thereby avoiding unnecessary extended resections. As in this report, a polypectomy via an antrotomy may be feasible.

\section{Case presentation}

A 46-year-old female presented with a 6-month history of intermittent non-bilious vomiting associated with weight loss. The previous history was non-contributory. The patient was pale and dehydrated. The only positive finding on abdominal examination was a succussion splash.

The admission haemoglobin was $6 \mathrm{~g} / \mathrm{dl}$. The biochemistry revealed compensated metabolic alkalosis, consistent with gastric outlet obstruction. Rectal exam confirmed melaena stool. A barium meal study revealed a filling defect in the second part of the duodenum (D2) (Figure 1A). At endoscopy a lesion occupying at least $75 \%$ of the 1 st part of the duodenal lumen (Figure 1B) was noted. CT scan confirmed this lesion, now noted in the $4^{\text {th }}$ part of the duodenum (D4) together with features of duodenal intussusception (Figure 1C, D). There were no features on CT scan to suggest an underlying malignancy. Biopsy of the lesion was not contributory. A provisional diagnosis of a benign polyp acting as a lead point causing intermittent duodenal intussusception was considered.

At laparotomy a duodeno-duodenal intussusception was noted and easily reduced. The predisposing polyp was easily milked into the antrum. Via an antrotomy the pedunculated polyp measuring $4.5 \mathrm{~cm}$ was resected (figure $2 \mathrm{~B}$ ). Histology confirmed a completely excised Brunner's gland adenoma. The patient was asymptomatic at the 6-month review. 

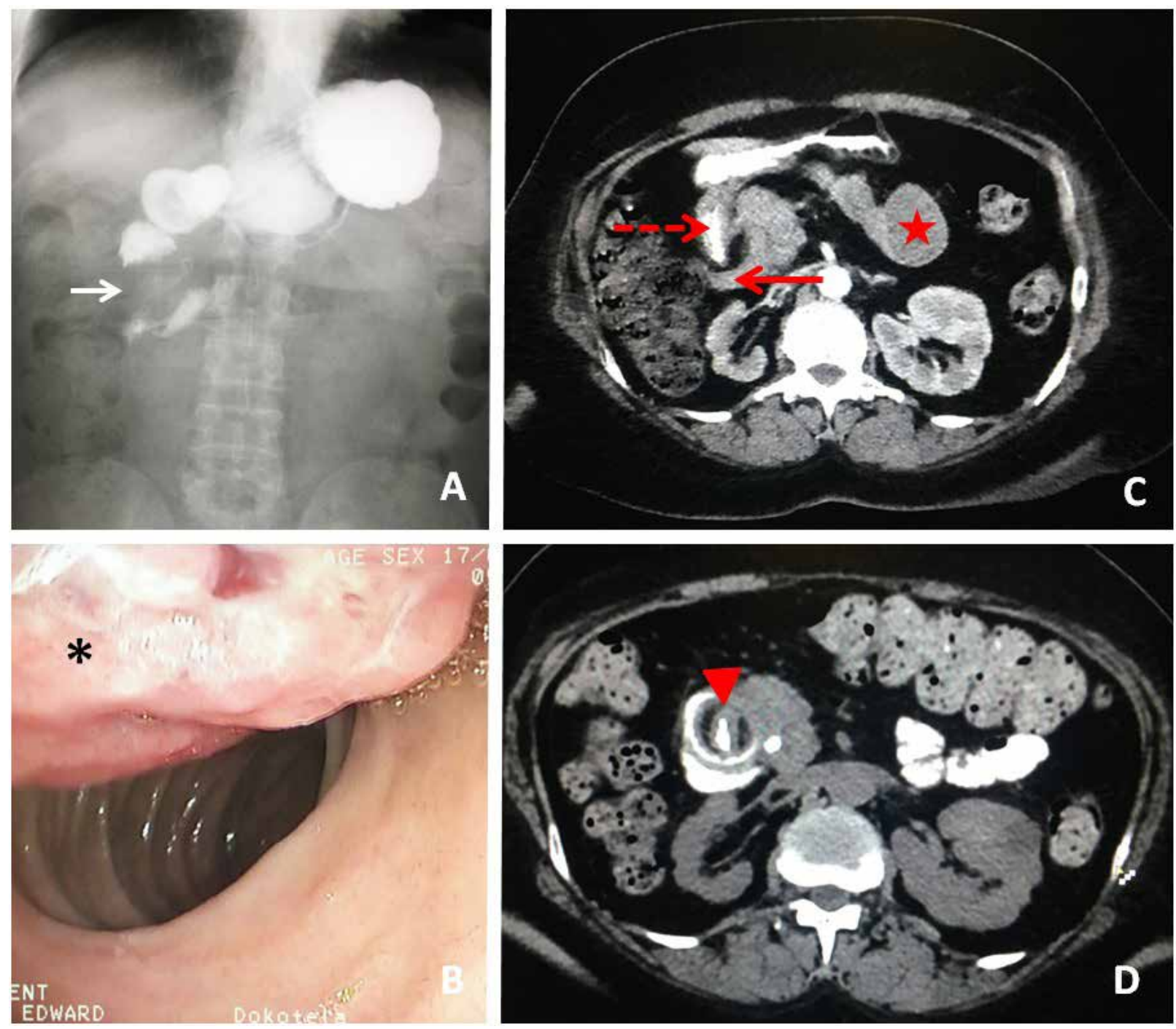

Figure 1: Barium meal, endoscopy and CT images of patient presenting with intussusception due to Brunner's adenoma A: Barium meal indicating filling defect in the 2 nd part of duodenum (D2), indicated by white arrow

B: Endoscopy with lesion indicated by asterisk, in 1st part of duodenum (D1)

$C$ and D: CT scan demonstrating intussuscepiens (solid arrow), intussuseptum (broken arrow), target sign (arrow head) with lead lesion (star) in $4^{\text {th }}$ part of the duodenum (D4)
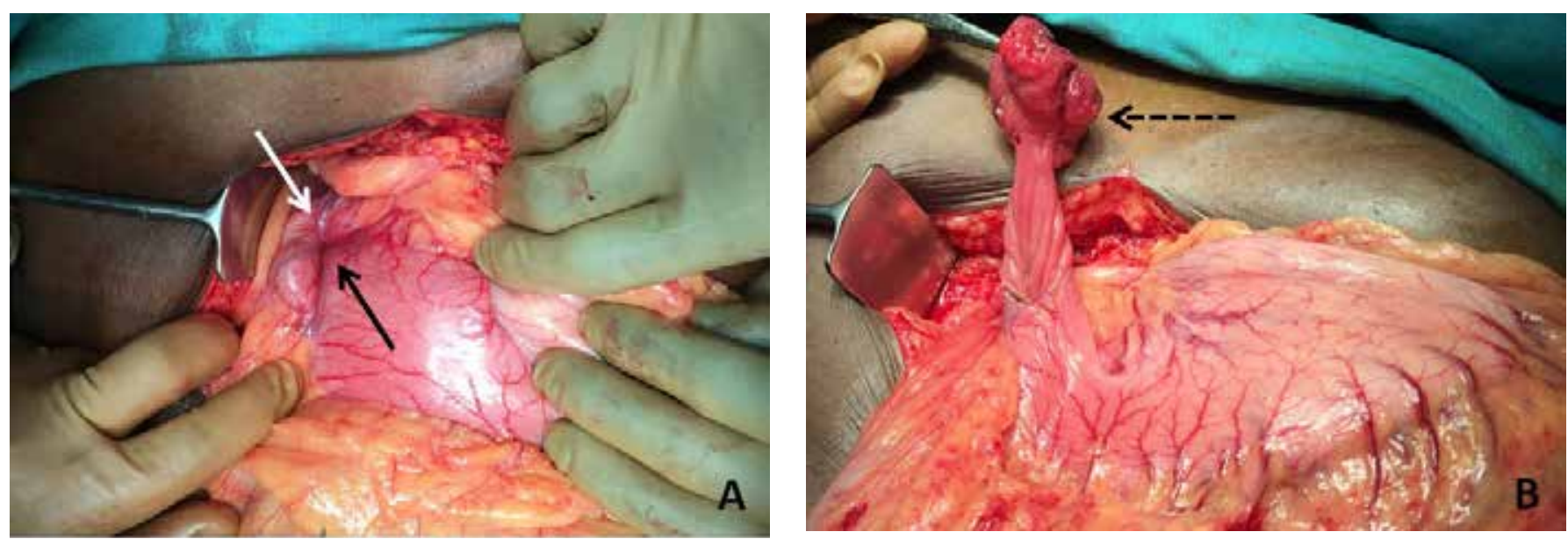

Figure 2: Intraoperative findings. A: Intussuscepiens (white arrow), intussuseptum (black arrow) due to Brunner's gland adenoma. B: Brunner's gland adenoma with stalk (broken arrow) arising from $1^{\text {st }}$ part of duodenum delivered via antrotomy 


\section{Discussion}

First described in 1688 by the Swiss anatomist Johann Conrad Brunner, Brunner's glands are mucin secreting glands found almost exclusively in the submucosa of the duodenum between the $1^{\text {st }}$ part (where they are most densely populated) to the 2 nd and rarely in the $3^{\text {rd }}$ and $4^{\text {th }}$ parts of the duodenum and proximal jejunum. Brunner's glands play a protective physiological role by secreting alkaline mucus which neutralizes the hydrochloric acid entering the duodenum. ${ }^{1}$

The Brunner's gland polyps are composed of hyperplastic Brunner's glands with intervening fibrous bands and connective tissue stroma that contains a mixture of ducts, adipose tissues and smooth muscles. The Brunner's gland polyp was first reported in 1835 by Curveilheir ${ }^{2}$ and is interchangeably referred to as Brunneromas, Brunner's gland adenomas and Brunner's hamartomas. According to Goldman, the most accurate description is that of a harmatoma, as the lack of encapsulation fits neither the criteria for an adenoma, nor hyperplasia. ${ }^{3}$

The pathogenesis of Brunner's gland adenomas is unknown; it is thought to be the result of increased acid exposure resulting in hyperplasia of the Brunner's glands. Helicobacter pylori may be implicated in the pathogenesis. These tumours exhibit a benign course and malignant transformation is extremely rare.

The majority of Brunner's gland adenomas are small and asymptomatic. The clinical presentation is commonly during the 5th and 6th decades without gender predominance. Lesions greater than $2 \mathrm{~cm}$ are rare and may present as duodenal obstruction, bleeding or pancreatitis. Due to the fixed position of the duodenum in the retroperitoneum it is not surprising that adenomas causing duodenal intussusception are extremely rare. True full thickness duodenal intussusception should be differentiated from mucosal intussusception on CT scan by a low attenuation fat plane between the bowel walls. This differentiation is significant in acute presentations as there is a higher risk of detrimental complications such as ischaemia in full thickness intussusception.

Duodenal intussusception secondary to Brunner's gland adenomas was first described in 1931 by Kellogg and subsequently, in 1959 , by Lempke., ${ }^{4,5}$ To date 12 cases (including this report) have been reported in the English literature (Table 1); however, this may be questionable

Table 1: Reported cases of duodenal intussusception secondary to Brunner's gland adenomas

\begin{tabular}{|c|c|c|c|c|c|c|}
\hline Case & Age & Sex & Presentation & Type of insussception & Diagnosis & Management \\
\hline Kellogg 1931 & 69 & M & $\begin{array}{c}\text { Intermittent GOO, } \\
\text { Anaemia }\end{array}$ & Duodeno-jejunal & $\begin{array}{l}\text { Abdominal } \\
\text { Radiograph }\end{array}$ & Pylorotomy + polypectomy \\
\hline Lempke 1959 & 22 & $\mathrm{~F}$ & Anaemia & Duodeno-jejunal & Barium meal & $\begin{array}{l}\text { Distal gastrectomy proximal } \\
\text { duodenum }\end{array}$ \\
\hline Rieth 1977 & 35 & $\mathrm{M}$ & Malena & Duodeno - jejunal & Endoscopy & duodenotomy + polypectomy \\
\hline Chaung 1991 & 15 & $\mathrm{~F}$ & $\begin{array}{l}\text { Postprandial } \\
\text { vomiting } \\
\text { Epigastric pain }\end{array}$ & Duodeno-jejunal & $\begin{array}{l}\text { Barium meal } \\
\text { endoscopy }\end{array}$ & duodenotomy + polypectomy \\
\hline Hwang 1997 & - & - & Malaena & Duodeno-jejunal & $\begin{array}{l}\text { Barium meal } \\
\text { endoscopy }\end{array}$ & duodenectomy \\
\hline Petersen 2008 & 56 & $\mathrm{~F}$ & GOO, epigastric pain & Duodeno - duodenal & CT scan & antrectomy + duodnectomy \\
\hline Bayan 2009 & 34 & $\mathrm{~F}$ & $\begin{array}{c}\text { Intermittent GOO, } \\
\text { Malaena } \\
\text { Epigastric pain }\end{array}$ & $\begin{array}{l}\text { Duodeno- jejunal with } \\
\text { intestinal malrotation }\end{array}$ & $\begin{array}{l}\text { Endoscopy } \\
\text { CT scan }\end{array}$ & duodenotomy + polypectomy \\
\hline Dhinakar 2010 & 56 & $\mathrm{~F}$ & Intermittent GOO & Duodeno -duodenal & $\begin{array}{l}\text { Barium meal } \\
\text { Endoscopy } \\
\text { CT scan }\end{array}$ & $\begin{array}{l}\text { Laparoscopic duodenotomy } \\
\text { + polypectomy }\end{array}$ \\
\hline Limi 2010 & 40 & $\mathrm{~F}$ & $\begin{array}{c}\text { Malena, epigastric } \\
\text { pain }\end{array}$ & Duodeno -duodenal & $\begin{array}{l}\text { Endoscopy } \\
\text { EUS } \\
\text { CT scan }\end{array}$ & $\begin{array}{l}\text { pyloroduodenotomy } \\
\text { polypectomy }\end{array}$ \\
\hline Uda 2016 & 57 & $\mathrm{~F}$ & $\begin{array}{l}\text { Malena, Epigastric } \\
\text { pain, GOO }\end{array}$ & Duodeno -jejunal & $\begin{array}{l}\text { Endoscopy } \\
\text { CT scan }\end{array}$ & Open duodenectomy \\
\hline Patankar 2016 & 31 & $\mathrm{~F}$ & $\begin{array}{l}\text { Epigastric pain, } \\
\text { Intermittent GOO }\end{array}$ & Duodeno-jejunal & $\begin{array}{l}\text { Endoscopy } \\
\text { EUS } \\
\text { CT scan }\end{array}$ & Open duodenectomy \\
\hline This report 2016 & 46 & $\mathrm{~F}$ & $\begin{array}{l}\text { Intermittent GOO, } \\
\text { Malena }\end{array}$ & Duodeno - duodenal & $\begin{array}{l}\text { Endoscopy } \\
\text { CT scan } \\
\text { Fluoroscopy }\end{array}$ & Antrotomy + polypectomy \\
\hline
\end{tabular}


given the vagaries in terminology, incomplete clinical documentation, advances in diagnostic techniques and surgical techniques that may preclude an accurate assessment of this rare condition.

The available literature suggests a female predominance with peak incidence during the $4^{\text {th }}$ to and $6^{\text {th }}$ decades. The diagnosis is difficult given the vague and non-specific symptoms. Endoscopy is the diagnostic modality of choice with fluoroscopy, CT scan, and endoscopic ultrasound used as adjuncts to the diagnosis. Perez et al. proposed that the method of excision of these lesions (surgical vs endoscopic) be based on their size and presence of submucosal extension on endoscopic ultrasonography. If submucosal extension is present, the cut-off polyp size for endoscopic polypectomy is $1 \mathrm{~cm}$; if there is no submucosal extension, the cut-off polyp size for endoscopic polypectomy is $2 \mathrm{~cm}^{6}$

\section{Conclusion}

Although exceedingly rare, duodenal intussusception secondary to Brunner's gland adenomas should be considered in female patients presenting with innocuous upper GIT bleeds with intermittent symptoms of gastric outlet obstruction. Multi-modal investigations for diagnosis prior to embarking on surgery are necessary to avoid unnecessary resections for these benign tumours. For open surgery, transduodenal or transpyloric polypectomy is classically recommended. However, if feasible, a trans-antral approach may be more forgiving than a duodenotomy (given the relative weakness of the duodenum) and the potentially deleterious effects of a pyloroplasty.

\section{Conflict of interest:}

All authors declare no conflict of interest.

\section{REFERENCES}

1. Brunner glands. (n.d.) Farlex Partner Medical Dictionary, 2012 [accessed 13 November 2016]. Available from: http://medicaldictionary.thefreedictionary.com/Brunner+glands

2. Cruveilhier J. Anatomie pathologique du corps humain. Paris: JB Balliere, 1835.

3. Goldman RL. Hamartomatous polyp of Brunner's gland. Gastroenterology. 1963;44:57-62.

4. Kellogg EL. Intussusception of the duodenum caused by adenoma originating in Brunner's glands. Med J Record. 1931;134:440-2.

5. Lempke RE. Intussusception of the duodenum: report of a case due to Brunner's gland hyperplasia. Ann Surg. 1959;150:160-6.

6. Perez A, Saltzman JR, Carr-Locke DL. Benign nonampullary duodenal neoplasms. J Gastrointest Surg. 2003;7:536-541. 